\title{
Identification of Fungi and Fungal Pathogens Associated with Hypolixus haerens and Decayed and Cankered Stems of Amaranthus hybridus
}

\author{
J. T. Blodgett, former Post-Doctoral Fellow, and W. J. Swart, Professor, Department of Plant Science, and S. vdM. \\ Louw, Professor, Department of Zoology \& Entomology, University of the Free State, P.O. Box 339, Bloemfontein \\ 9300, South Africa
}

\begin{abstract}
Blodgett, J. T., Swart, W. J., and Louw, S. vdM. 2004. Identification of fungi and fungal pathogens associated with Hypolixus haerens and decayed and cankered stems of Amaranthus hybridus. Plant Dis. 88:333-337.

Discoloration, cankers, and decay in branches, stems, and root collars of Amaranthus hybridus were observed in Bloemfontein, South Africa. Examination of symptomatic stems revealed larval galleries of the pigweed weevil (Hypolixus haerens). The objectives of this study were to: identify the most common fungal species associated with this damage, determine if the adult pigweed weevil might be a vector for the fungi, and test if the associated fungi can cause the stem canker disease observed in the field. The most common fungal species isolated were Fusarium subglutinans from discolored tissues adjacent to insect galleries (42\%), F. subglutinans from weevil larvae (29\%), the Alternaria tenuissima group from adult weevils (31\%), and the $A$. tenuissima group from cankered stems $(40 \%)$. Three of the seven most common fungal species produced cankers following wounding and inoculation, with $F$. sambucinum and $F$. oxysporum being the most aggressive. Although fungal species compositions differed $(P<0.01)$ among the four tissue/insect stage combinations tested, all four had the same major fungal species, suggesting the pigweed weevil as a vector for the Fusarium pathogens. There is significant potential for yield loss affiliated with this insect-fungal association. The identification of this insect-fungal relationship and the pathogens involved in disease set the stage for further research on the etiology and disease management of this important insect-fungal relationship.
\end{abstract}

Additional keywords: amaranth, Fusarium equiseti, F. solani, insect vectoring, smooth amaranthus

Amaranthus hybridus (common names: smooth amaranthus or amaranth) is a fastgrowing vegetable crop with edible leaves that are highly nutritious $(30,33)$. Amaranthus species are used as alternative crops throughout the world, growing well in semiarid regions $(21,22,33)$. In southern Africa, cultivation of this crop as a leafy vegetable is increasing. A. hybridus has considerable potential for increased commercial application worldwide. However, a sustainable integrated pest/disease management approach for the cultivation of $A$. hybridus requires an understanding of abiotic and biotic factors that can affect this important food crop.

The pigweed weevil, Hypolixus haerens (Coleoptera: Curculionidae), is the main insect pest of A. hybridus in South Africa (26). The adult weevil primarily lays its

Corresponding author: J. T. Blodgett

E-mail: jblodgett@fs.fed.us

Current address of J. T. Blodgett: USDA-Forest Service, Forest Health Management, 1730 Samco Rd., Rapid City, SD 57702.

Accepted for publication 29 October 2003.

Publication no. D-2004-0127-02R

(C) 2004 The American Phytopathological Society eggs in branch crotches, and the larvae bore through stems to the root collars, causing a hollowing of stems. This larval feeding results in stems that are more susceptible to wind breakage, increasing crop losses. The weevil overwinters in the dying and deteriorating stems as mature larvae and/or pupae. In the spring, weevils eclose and immediately feed on leaves of $A$. hybridus and other plants.

Insect-fungal interactions have long been known to result in severe crop losses of many host species $(1,3,11,17)$. In autumn 1997, extensive tissue discoloration and decay were observed in most branches, stems, and root collars of mature A. hybridus in two plots in Bloemfontein, Free State Province, South Africa (9). Symptoms included discolored phloem, xylem, and pith; black cankers on stems and root collars; and weakened stems prone to wind breakage. Examination of these tissues revealed larval galleries of the pigweed weevil in all symptomatic stems. The adult weevil causes wounds to plant tissues during feeding and egg laying, and the larvae cause wounds to plant tissues during feeding (26). Insect involvement in the transmission of fungal pathogens is well documented (1). However, the possibility that the pigweed weevil might be a vector of the observed canker disease has never been described.
The potential role of the weevilassociated fungi in causing disease of Amaranthus stems colonized by $H$. haerens was investigated in this study. The objectives of this study were to identify common fungal species in the following settings: (i) associated with tissue decay and discoloration in larval galleries of the pigweed weevil, (ii) carried on the larvae, (iii) carried by the adult insects as they fly to new hosts, and (iv) on the cankered stems and root collars; (v) to test if the more common fungi identified might be involved in the branch, stem, and root collar diseases observed in the field; and (vi) to examine if water stress can stimulate colonization of stems. Water stress was investigated since A. hybridus is often grown in semiarid regions $(21,22,33)$, and soil moisture extremes have been associated with many diseases, including those caused by Fusarium species $(5,27,37)$. Studies were conducted in cultivated monoculture fields at two sites in South Africa, and in a greenhouse using plants grown from seed.

\section{MATERIALS AND METHODS}

Field plot establishment. A. hybridus fields were established at two sites $(20 \mathrm{~km}$ apart; sites A and B) in Bloemfontein, South Africa. The fields were mechanically cultivated using tine implements at both sites. Smooth amaranthus seeds were sown in seed trays in a sand-loam (10 to $15 \%$ clay) and peat moss (Les Tourbes Niron, Riviere du Loup, Québec, Canada) mixture $(1: 1 \mathrm{vol} / \mathrm{vol})$. Soils were steam-pasteurized twice for $1 \mathrm{~h}$ at $80^{\circ} \mathrm{C}$ before planting seeds $10 \mathrm{~mm}$ deep. Plants were watered to field capacity daily and were fertilized by adding $50 \mathrm{ml}$ per seed tray of a $3 \mathrm{~g} /$ liter hydroponic nutrient solution (6.5:2.7:13 $\mathrm{N}: \mathrm{P}: \mathrm{K}$ plus micronutrients) once a week as a soil drench for 30 days. Thirty-day-old plants were transplanted to the field in mid-November at both sites. After placing plants in planting holes, the holes were filled with water and then with soil. At both sites, fields were $40.8 \mathrm{~m}$ long and 20 rows wide, with an intra-row spacing of $0.3 \mathrm{~m}$ and $1.5-\mathrm{m}$ spacing between rows, resulting in approximately 2,720 plants per field. A drip-line irrigation system delivered approximately $40 \mathrm{~mm}$ of water for $2 \mathrm{~h}$ every other day at each site.

Field isolations and identification. Ten cankered, 6-month-old A. hybridus stems 
were collected from each of the two sites in June 1997. Stems/root collars were split and eight small samples of approximately $64 \mathrm{~mm}^{3}$ (approximately $4 \times 4 \times 4 \mathrm{~mm}$ ) of discolored pith, xylem, or phloem tissues adjacent to larval galleries were aseptically transferred from each stem to cornmeal agar (CMA; Oxoid, Basingstoke, England) containing $0.3 \mathrm{ml}$ of streptomycin sulfate (at $1 \mathrm{~g}$ a.i. per $3 \mathrm{ml}$ ) per liter and incubated at $24^{\circ} \mathrm{C}$. A total of 160 isolation attempts were made. CMA is a general purpose medium for isolating fungi. The associated larvae were extracted from the same stems/root collars (48 larvae from site A; 40 larvae from site B), decapitated with a tweezer, and plated directly on CMA in petri plates that were incubated at $24^{\circ} \mathrm{C}$. After 4 to 7 days, fungi growing from the tissues or larvae were transferred from colony margins onto separate $1.5 \%$ water agar (WA; Oxoid) plates. Isolates were later transferred to half-plates of carnation leaf agar/potato dextrose agar (Oxoid) for identification (28). Carnation leaf agar and potato dextrose agar work well for identification of many fungal species. Therefore, the same methods were used to identify all fungal species. Plates were incubated in a growth chamber with $16 \mathrm{~h}$ of light per day and temperatures of $25^{\circ} \mathrm{C}$ day and $20^{\circ} \mathrm{C}$ night. Percent recovery can exceed $100 \%$ due to multiple isolates from individual tissue samples or larvae. Reporting percentages above $100 \%$ clearly show when multiple species co-occur in tissues and also clearly show the percentage of times each species is recovered.

Five additional asymptomatic stems not harboring insect larvae were collected from each site at the same time. The stems/root collars were split, and eight small samples of approximately $64 \mathrm{~mm}^{3}$ (approximately $4 \times 4 \times 4 \mathrm{~mm}$ ) of healthyappearing pith, xylem, or phloem tissues were aseptically transferred from each stem to CMA and incubated at $24^{\circ} \mathrm{C}$. A total of 80 isolation attempts were made. After 4 to 7 days, any fungal colonies growing from the tissues were transferred from colony margins, incubated, and identified as previously described.

Three cankered stem segments (approximately $5 \mathrm{~cm}$ long) from each of 10 stems were collected from each of the two sites 2 weeks later. Segments were placed in moist chambers for 3 weeks. Fungal hyphae growing from the stem surfaces were collected with a scalpel, transferred to CMA, and incubated at $24^{\circ} \mathrm{C}$. A total of 60 such isolation attempts were made. After 5 to 7 days, mycelia from the colony margins were transferred, incubated, and identified as previously described.

In October 1997, stems/root collars collected from the same two sites were split, and pre-emergent adult weevils and recently emerged adult weevils were aseptically transferred, after decapitation with a tweezer, to CMA and incubated at $24^{\circ} \mathrm{C}$.
At the time of collection, the adult weevil population was exiting stems. Forty adults from site $\mathrm{A}$ and 33 adults from site $\mathrm{B}$ were collected. After 4 to 7 days, fungal colonies growing from weevils were transferred from colony margins, incubated, and identified as previously described.

Inoculation experiment: planting and greenhouse conditions. Smooth amaranthus plants were established in 500-ml pots in a soil mix (vol/vol) of $50 \%$ sand-loam (10 to $15 \%$ clay) and $50 \%$ peat moss. Soils were steam-pasteurized twice for $1 \mathrm{~h}$ at $80^{\circ} \mathrm{C}$ before planting seeds $10 \mathrm{~mm}$ deep. Plants were watered to field capacity daily and were fertilized by adding $50 \mathrm{ml}$ per pot of a $3 \mathrm{~g} /$ liter hydroponic nutrient solution (6.5:2.7:13 N:P:K plus micronutrients) once a week as a soil drench. Six-week-old plants were transplanted into 2-liter pots containing the same soil mix as the 500-ml pots.

Two weeks after transplanting, plants were supplemented with artificial light to provide a 16-h photoperiod. Photon flux density of the supplemented light averaged $18 \mu \mathrm{E} \cdot \mathrm{s}^{-1} \cdot \mathrm{m}^{-2}$ with a maximum recorded ambient greenhouse photon flux density of $1,233 \mu \mathrm{E} \cdot \mathrm{s}^{-1} \cdot \mathrm{m}^{-2}$. The average greenhouse temperature was $25^{\circ} \mathrm{C}$ during the day and $17^{\circ} \mathrm{C}$ at night, and the average relative humidity $(\mathrm{RH})$ was $78 \%$ during the day and $94 \%$ at night. The floors and walls of the greenhouse were sprayed with water twice a day, 7 days a week, to maintain the high RH. High RH was used to reduce water loss in plants, thus extending the period of water stress. Plants were placed on a bench flooded with water to allow continuous water contact with the bottom of the pots.

Inoculation experiment: water stress. Four weeks after transplanting (mid-April and early June for the repetition, 1998), half the plants (45 plants; 90 total plants in each of two trials) were placed on stands suspending them above the water (water stressed), and the remaining plants were allowed continuous water contact with the bottom of the pots (non-water stressed). Host water stress was included in this study since $A$. hybridus is often grown in semiarid regions, such as South Africa, and soil moisture extremes have been associated with various diseases, including those caused by Fusarium species $(5,27,37)$. A pressure bomb (36) was used periodically to measure the mean predawn leaf water potentials $\left(\psi_{\mathrm{PD}}\right)$ of five randomly selected plants of each water treatment. When the mean $\psi_{\mathrm{PD}}$ of the water-stressed plants fell below $-2.0 \mathrm{MPa}$, all plants were watered to field capacity. A $\psi_{\mathrm{PD}}$ of $-2.0 \mathrm{MPa}$ was reached twice in both trials.

Inoculation experiment: wounding and inoculation. After 1 week under the different watering regimes, stems were inoculated with seven of the more common fungal species isolated from the stems and insects. One single-spore isolate of each of the following species was used: Fusarium subglutinans, $F$. oxysporum, $F$. sambucinum, F. solani, Alternaria tenuissima group, a Phomopsis sp., and a Phoma sp. (five replications per watering regime/isolate treatment combination). Inoculations involved wounding a stem by removing approximately $6 \times 6 \mathrm{~mm}$ of the epidermis $5 \mathrm{~cm}$ above the soil with a scalpel. Wound inoculations were used in this study because both the adult weevil and the larvae cause physical damage to $A$. hybridus and other plant species. Five-mmdiameter WA plugs cut from margins of actively growing cultures were placed mycelium-side-down on the wounds. Parafilm (American National Can Co., Chicago, IL) was wrapped around the plug and stem. Wounded and nonwounded (untreated) controls were also included. Noncolonized WA plugs were applied to wounded controls but not to nonwounded controls. Five plants per watering regime/isolate treatment combination, and five wounded and nonwounded control plants for each watering regime, were used in each of two completely randomized independent trials, separated by 2 months. A total of 180 plants were used. Since all treatments were assigned randomly, a completely randomized experimental design was used in the analyses.

Inoculation experiment: observations and measurements. Canker lengths and percentage of the stem circumference cankered were measured (if present) 4 weeks after inoculation. Fungal recovery also was attempted 4 weeks after inoculation from all stems, including stems of the two control treatments. Stem segments were surface-disinfested in a series of $1 \mathrm{~min}$ in $96 \%$ ethanol, $5 \mathrm{~min}$ in a $3.5 \% \mathrm{NaOCl}$ solution (wt/vol), and $30 \mathrm{~s}$ in $96 \%$ ethanol. Tissues (approximately $5 \times 5 \mathrm{~mm}$ ) from the wound sites or from a canker (if present) were then cut from the stems using a scalpel. The tissues were aseptically placed in individual WA plates and incubated for 21 days at ambient laboratory temperature (approximately $24^{\circ} \mathrm{C}$ ) and light. Presence of the inoculated fungi in the incubated stem tissues was confirmed by examining resulting mycelia and spores.

Statistical analyses. Chi-square analyses were used to examine the composition of fungal species isolated from stems/insects in relation to geographic location (site A and B) and source of isolation (stems/insects). For the inoculation experiment, chi-square analyses were also used to examine incidence of disease and recovery after inoculation in relation to watering regime (two levels), inoculation treatment (nine levels), and trial (two levels). Canker lengths and circumferences were analyzed by three-factor analyses of variance with all interactions. Factors used as the main effects were watering regime (two levels), inoculation treatment (nine levels), and trial (two levels). Five replica- 
tions were used per watering regimeinoculation treatment-trial combination, with a total of 180 plants used in the inoculation experiment. The canker lengths and circumferences were analyzed both untransformed and after $\log e(x+1)$ and $\operatorname{sqrt}(x+1)$ transformations were applied. Because the $P$ values and resulting conclusions were similar for all forms of analysis, results are reported only for the untransformed data. $\psi_{\mathrm{PD}}$ from the inoculation experiment were analyzed by one-way analyses of variance with watering regime (two levels) as the factor. Chi-square analyses and analyses of variance using general linear model procedure were performed using Minitab for Windows, release 10.2 (Minitab Inc., State College, PA).

\section{RESULTS}

Field isolations. Fungal isolation from symptomatic $A$. hybridus and from $H$. haerens larvae and adults was successful. However, few isolates were recovered from asymptomatic stem tissues (5\% recovery from site A and $0 \%$ from site B). Recovery from: larval galleries yielded isolates $100 \%$ of the time from site A and 108\% from site $\mathrm{B}$; larvae yielded isolates $108 \%$ of the time from site A and $104 \%$ from site B; adult weevils yielded isolates $193 \%$ of the time from site $\mathrm{A}$ and $176 \%$ from site $\mathrm{B}$; and cankered stems yielded isolates $117 \%$ of the time from site A and 93\% from site B.

Several fungal species were isolated from symptomatic $A$. hybridus tissues and from $H$. haerens larvae and adults (Table 1). The most common species isolated from discolored tissues adjacent to insect galleries was $F$. subglutinans $(42 \%)$; from weevil larvae was $F$. subglutinans (29\%); from adult weevils was the Alternaria tenuissima group (31\%); and from cankered stems was the A. tenuissima group $(40 \%)$. Other common species isolated from the stems and weevils included $F$. oxysporum, $F$. equiseti, $F$. solani, $F$. sambucinum, Epicoccum spp., a Phomopsis sp., and Phoma spp. Only two isolates were recovered from asymptomatic stem tissues, a Chaetomium sp., and a Penicillium sp.

There were significant differences between the two sites in fungal species compositions for larval gallery tissues $(P<$ $0.01)$, adult weevils $(P=0.02)$, and cankered surface stem tissues $(P<0.01)$, but not for larvae $(P=0.10)$. However, several of the same species were isolated from both sites (Table 1). Significant differences $(P<0.01)$ in fungal species composition also occurred among $A$. hybridus tissues, larvae, and adults. Although species compositions differed among the four tissue/insect stage combinations examined, all four had the same major species.

Inoculation experiment. Significant differences in mean $\psi_{\mathrm{PD}}(P<0.001)$ between plants of the two watering regimes were measured in both trials of the greenhouse experiment. Before watering, the lowest water potential readings of stressed plants averaged $-2.1 \mathrm{MPa}$ in both trials, while the nonstressed plants averaged -0.1 MPa for all readings. However, the effect of water treatment was not significant on canker length $(P=0.94)$, canker width $(P$ $=0.99)$, incidence of symptoms $(P=0.87)$, or recovery of fungi $(P=0.76)$. The trial effect also was not significant on canker length $(P=0.11)$, canker width $(P=0.65)$, incidence of symptoms $(P=0.64)$, or recovery of fungi $(P=0.37)$. Therefore, results for canker length, canker width, incidence of symptoms, and recovery of fungi are combined for plants inoculated with the same fungal isolate, regardless of water treatment and trial.

The inoculation treatment was significant $(P<0.001)$ for incidence of symp- toms, canker length, canker width, and recovery of fungi (Table 2). Only three of the seven species tested, $F$. sambucinum, $F$. oxysporum, and $F$. subglutinans, produced cankers. Lesions were never observed on stems inoculated with the other isolates, and lesions were never observed on either wounded or nonwounded control stems. Discoloration and canker symptoms were the same as symptoms observed in the field, and symptoms were first observed 5 days after inoculation in both trials. The isolates were recovered from stems inoculated with all species (Table 2), with slightly higher recoveries from some of the species that did not produce symptoms. None of the Fusarium spp. were recovered from either of the two control treatments ( $n$ $=20$ for each species tested).

\section{DISCUSSION}

The present investigation has demonstrated that numerous species of fungi are associated with $H$. haerens, a phytophagous weevil on A. hybridus. Three of the common fungal species isolated from four tissue/insect stages, $F$. sambucinum, $F$. oxysporum, and $F$. subglutinans, were shown in artificial inoculations to be independently pathogenic to the host plant. These Fusarium species are likely the cause of the discoloration, decay, and cankers observed in branches, stems, and root collars of mature A. hybridus. However, $H$. haerens larvae were observed in all symptomatic stems in the field.

Although the Alternaria tenuissima group was the most common isolated from cankered stems, this species group did not cause stem cankers in our study. Fusarium spp. also were isolated from cankered stems, and from the weevil larval galleries and larvae. The low recovery of fungi from asymptomatic, epidermal stem tissues collected from the same sites 1 month

Table 1. Species composition (percentages) of fungi isolated from Hypolixus haerens larval galleries, larvae, and adults, and cankered stems of Amaranthus hybridus

\begin{tabular}{|c|c|c|c|c|c|c|c|c|}
\hline \multirow[b]{2}{*}{ Fungal species/genera } & \multicolumn{2}{|c|}{ Larval galleries } & \multicolumn{2}{|c|}{ Larvae } & \multicolumn{2}{|c|}{ Adults } & \multicolumn{2}{|c|}{ Cankered stems } \\
\hline & Site A & Site B & Site A & Site B & Site A & Site B & Site A & Site B \\
\hline Fusarium subglutinans & 32 & 51 & 26 & 31 & 6 & 7 & 11 & 9 \\
\hline F. oxysporum & 11 & 15 & 22 & 19 & 3 & 8 & 11 & 6 \\
\hline F. equiseti & 1 & $\ldots{ }^{\mathrm{w}}$ & 9 & 10 & 5 & 14 & 18 & 3 \\
\hline F. solani & 2 & 8 & 6 & 8 & 2 & 4 & 8 & 15 \\
\hline F. sambucinum & 7 & $\ldots$ & 5 & 3 & 14 & 4 & 13 & 4 \\
\hline F. proliferatum & 3 & 1 & 2 & 3 & $\ldots$ & 3 & $\ldots$ & 4 \\
\hline F. culmorum & $\ldots$ & $\ldots$ & $\ldots$ & $\ldots$ & $\ldots$ & $\ldots$ & 2 & $\ldots$ \\
\hline Alternaria tenuissima group & 6 & 14 & 3 & 9 & 38 & 24 & 33 & 47 \\
\hline Epicoccum spp. & $\ldots$ & $\ldots$ & ... & 4 & 16 & 24 & $\ldots$ & $\ldots$ \\
\hline Phomopsis sp. & 21 & $\ldots$ & 8 & $\ldots$ & $\ldots$ & $\ldots$ & $\ldots$ & $\ldots$ \\
\hline Phoma spp. & 6 & 4 & 2 & 1 & 8 & 4 & $\ldots$ & $\ldots$ \\
\hline Microdochium spp. & 5 & 2 & 6 & 3 & 1 & $\ldots$ & $\ldots$ & $\ldots$ \\
\hline Other identified isolates ${ }^{x}$ & 5 & 1 & 4 & 2 & 4 & 3 & 1 & 4 \\
\hline Unidentified isolates $\mathrm{S}^{\mathrm{y}}$ & 1 & 4 & 7 & 7 & 3 & 5 & 3 & 8 \\
\hline $\mathrm{N}^{2}=$ & 80 & 86 & 52 & 42 & 77 & 58 & 35 & 28 \\
\hline
\end{tabular}

${ }^{\mathrm{w}}$ Fungi were not isolated.

${ }^{x}$ Less common species including: Rhizopus spp., Alternaria spp. other than the A. tenuissima group, basidiomycete species, Phytophthora spp., Chaetomium spp., Acremonium spp., Penicillium spp., oomycete species, and Trichoderma spp.

${ }^{\mathrm{y}}$ Includes nonsporulating mycelial fungi.

${ }^{\mathrm{z}}$ Total number of isolates. 
prior to this study (10) suggests that the $A$. tenuissima group and other non-Fusarium species infect during or soon after the Fusarium species.

Plant diseases caused by Fusarium species have been associated with several insects $(14,23,24)$. Weevils, in particular, have been associated with various fungal pathogens $(13,15,29)$, including Fusarium spp. $(18,20,25)$. In the insect-fungal-plant relationship we investigated on amaranth, adult pigweed weevils might act as a vector for Fusarium species, and/or might produce the infection site by host wounding when eggs are laid. Healthy, insect free pith, xylem, and phloem stem tissues yielded few fungal isolates, and never yielded the Fusarium species. Fungi are also infrequent or absent in asymptomatic, epidermal stem tissues collected from the field (10). Fusarium was the most common genus associated with the discolored stem tissue around larval galleries, and the most common genus associated with $H$. haerens larvae. The recovery of many of the same Fusarium species from cankered stems and from the adult insects, although in lower percentages than the Alternaria tenuissima group, supports the hypothesis of introduction of these pathogens by the weevil. Isolation attempts from the spotted maize beetle (Astylus atromaculatus) and the tarnished plant bug (Lygus lineolaris), other common insects on A. hybridus, did not result in the recovery of Fusarium species (J. T. Blodgett, W. J. Swart, and S. vdM. Louw, unpublished). This indicates that $H$. haerens might be an important vector of the Fusarium pathogens of $A$. hybridus.

Water stress is known to influence many plant diseases. Water stress is associated with enhancement of disease development on several host species by many pathogens
$(2,4,6,8,32,34,35)$. However, water stress also may have a neutral or negative influence on the development of certain plant diseases $(7,19,38,39)$. Fusarium diseases can be enhanced by high or by low soil moisture extremes $(5,27,37)$. In our study, results indicate that even extreme water stress of A. hybridus plants does not significantly affect the development of stem cankers by any of the seven fungal species tested.

In a previous study (10), some of the same fungal species associated with $A$. hybridus were described as being endophytic or quiescent in this host. Endophytic or latent Fusarium spp. have also been reported from other plant hosts $(12,16,31)$. The potential ability of endophytic Fusarium isolates in $A$. hybridus to act as latent pathogens when induced by wounding such as weevil damage therefore deserves further investigation.

It is not known if these fungal species cause significant disease on this host independent of the weevil. However, the fact that these insect-fungal associations were firmly established is important information when developing an integrated pest management program for the cultivation of $A$. hybridus in South Africa. Further studies are therefore needed to determine the role of these pathogenic fungi in weakening Amaranthus stems colonized by the pigweed weevil.

\section{ACKNOWLEDGMENTS}

We thank G. R. Stanosz and W. C. Schaupp, Jr., for presubmission reviews. The assistance by J. Rheeder and F. Kloppers with the identification of Fusarium spp. was greatly appreciated. We also thank P. Mohasi, W. Kriel, and M. Molemela for technical assistance. Financial support was provided by the National Research Foundation (formerly Foundation for Research Development) of South Africa.

Table 2. Incidence of symptoms ${ }^{\mathrm{u}}$, canker lengths, and canker widths on inoculated ${ }^{\mathrm{v}}$ Amaranthus hybridus stems, and percentages of stems from which the inoculated fungi were recovered ${ }^{\mathrm{w}} 4$ weeks after inoculation

\begin{tabular}{lcccc}
\hline $\begin{array}{l}\text { Inoculation } \\
\text { treatment }^{\mathbf{x}}\end{array}$ & $\begin{array}{c}\text { Incidence of } \\
\text { symptoms } \mathbf{( \% )}\end{array}$ & $\begin{array}{c}\text { Canker length } \\
(\mathbf{m m})\end{array}$ & $\begin{array}{c}\text { Canker } \\
\text { circumference (\%) }\end{array}$ & $\begin{array}{c}\text { Recovery } \\
(\boldsymbol{\%})\end{array}$ \\
\hline Fusarium sambucinum & $100^{\mathrm{y}}$ & 30 & 75 & 65 \\
F. oxysporum & 100 & 26 & 43 & 50 \\
F. subglutinans & 65 & 10 & 17 & 60 \\
F. solani & 0 & 0 & 0 & 70 \\
Alternaria tenuissima & 0 & 0 & 0 & 75 \\
group & 0 & 0 & 0 & 95 \\
Phomopsis sp. & 0 & 0 & 0 & 55 \\
Phoma sp. & $P<0.001$ & $P<0.001$ & $P<0.001$ & $P<0.001$ \\
Significance $^{\mathrm{z}}$ & &
\end{tabular}

" Symptoms included black cankers and were the same as symptoms observed in the field.

${ }^{\mathrm{v}}$ Inoculations involved wounding a stem by removing approximately $6 \times 6 \mathrm{~mm}$ of the epidermis $5 \mathrm{~cm}$ above the soil with a scalpel and inoculating with a 5-mm-diameter water agar plug cut from margin of actively growing cultures.

${ }^{w}$ Presence of inoculated fungi were confirmed from surface-disinfested tissues.

${ }^{x}$ All single-spore isolates. Results are pooled across trials and across water treatments since those effects were not significant.

${ }^{y} \mathrm{~N}=20$ for each species tested with a total of 180 plants used in the study, including wounded and nonwounded (untreated) controls.

${ }^{z}$ Chi-square analyses were used to examine incidence of symptoms and recovery after inoculation. Canker lengths and circumferences were analyzed by analyses of variance.
LITERATURE CITED

1. Agrios, G. N. 1980. Insect involvement in the transmission of fungal pathogens. Pages 293234 in: Vectors of Plant Pathogens. F. K. Harris and K. Maramorosch, eds. Academic Press, New York.

2. Appel, D. N., and Stipes, R. J. 1984. Canker expansion on water-stressed pin oaks colonized by Endothia gyrosa. Plant Dis. 68:851853.

3. Austwick, P. K. C. 1958. Insects and the Spread of Fungal Disease, Biological Aspects of the Transmission of Disease. Oliver and Boyd, London.

4. Bagga, D. K., and Smalley, E. B. 1974. The development of hypoxylon canker of Populus tremuloides: Role of interacting environmental factors. Phytopathology 64:658-662.

5. Beddis, A. L., and Burgess, L. W. 1992. The influence of plant water stress on infection and colonization of wheat seedlings by Fusarium graminearum group 1. Phytopathology 82:7883.

6. Bertrand, P. F., English, H., Uriu, K., and Schick, F. J. 1976. Late season water deficits and development of Cytospora canker in French prune. Phytopathology 66:1318-1320.

7. Biggs, A. R., Davis, D. D., and Merrill, W. 1983. Cutting development and restriction of wound-associated infection in Populus. Can. J. Plant. Pathol. 5:269-272.

8. Blodgett, J. T., Kruger, E. L., and Stanosz, G. R. 1997. Effects of moderate water stress on disease development by Sphaeropsis sapinea on red pine. Phytopathology 87:422-428.

9. Blodgett, J. T., Swart, W. J., and Louw, S vdM. 1998. First report of Fusarium sambucinum, $F$. oxysporum, and $F$. subglutinans associated with stem decay of Amaranthus hybridus in South Africa. Plant Dis. 82:1062.

10. Blodgett, J. T., Swart, W. J., Louw, S. vdM., and Weeks, W. J. 2000. Species composition of endophytic fungi in Amaranthus hybridus leaves, petioles, stems, and roots. Mycologia 92:853-859.

11. Carter, W. 1973. Insects in Relation to Plant Disease, 2nd ed. John Wiley \& Sons, London.

12. Fisher, P. J., and Petrini, O. 1992. Fungal saprobes and pathogens as endophytes of rice (Oryza sativa L.). New Phytol. 120:137-143.

13. Friedli, J., and Bacher, S. 2001. Mutualistic interaction between a weevil and a rust fungus, two parasites of the weed Cirsium arvense. Oecologia 129:571-576.

14. Gillespie, D. R., and Menzies, J. G. 1993 Fungus gnats vector Fusarium oxysporum f. sp. radicis-lycopersici. Ann. Appl. Biol. 123:539-544.

15. Halik, S., and Bergdahl, D. R. 2002. Potential beetle vectors of Sirococcus clavigignentijuglandacearum on butternut. Plant Dis. 86:521-527.

16. Hallmann, J., and Sikora, R. A. 1994. Occurrence of plant parasitic nematodes and nonpathogenic species of Fusarium in tomato plants in Kenya and their role as mutualistic synergists for biological control of root-knot nematodes. Int. J. Pest Manag. 40:321-325.

17. Hatcher, P. E. 1995. Three-way interactions between plant pathogenic fungi, herbivorous insects and their plant hosts. Biol. Rev. 70:639-694.

18. Hill, R. R., Jr., Newton, R. C., Zeiders, K. E., and Elgin, J. H. 1968. Relationships of the clover root curculio, Fusarium wilt, and bacterial wilt in alfalfa. Crop Sci. 9:327-329.

19. Jacobi, W. R., and Riffle, J. W. 1989. Effects of water stress on Thyronectria canker of honeylocusts. Phytopathology 79:1333-1337.

20. Kalb, D. W., Bergstrom, G. C., and Shields, E. J. 1994. Prevalence, severity, and association of fungal crown and root rots with injury by the clover root curculio in New York alfalfa. Plant Dis. 78:491-495. 
21. Kauffman, C. S., and Haas, P. W. 1983. Grain amaranth: A crop with low water requirements and high nutritional value. Pages 299-313 in: Environmentally Sound Agriculture: Selected Papers from the 4th International Conference of the International Federation of Organic Agriculture Movements. W. Lockeretz, ed. Praeger, NY.

22. Kauffman, C. S., and Weber, L. E. 1990. Grain amaranth. Pages 127-139 in: Advances in New Crops. Proc. Nat. Sympos. New Crops, Res., Development, Economics. 1st. J. Janick and J. E. Simon, eds. Timber Press, Portland, OR.

23. Kemp, G. H. J., Pretorius, Z. A., and Wingfield, M. J. 1996. Fusarium glume spot of wheat: A newly recorded mite-associated disease in South Africa. Plant Dis. 80:48-51.

24. Leath, K. T., and Byers, R. A. 1977. Interaction of Fusarium root rot with pea aphid and potato leafhopper feeding on forage legumes. Phytopathology 67:226-229.

25. Leath, K. T., and Hower, A. A. 1993. Interaction of Fusarium f. sp. medicaginis with feeding activity of clover root curculio larvae in alfalfa. Plant Dis. 77:799-802.

26. Louw, S. vdM., Van Eeden, C. F., and Weeks, W. J. 1995. Curculionidae (Coleoptera) associated with wild and cultivated Amaranthus spp. (Amaranthaceae) in South Africa. Afr. Crop Sci. J. 3:93-98.
27. Mergoum, M., Hill, J. P., and Quick, J. S. 1998. Evaluation of resistance of winter wheat to Fusarium acuminatum by inoculation of seedling roots with single, germinated macroconidia. Plant Dis. 82:300-302.

28. Nelson, P. E., Toussoun, T. A., and Marasas, W. F. O. 1983. Fusarium Species: An Illustrated Manual for Identification. Pennsylvania State University, University park.

29. Nevill, R. J., and Alexander, S. A. 1992. Transmission of Leptographium procerum to eastern white pine by Hylobius pales and Pissodes nemorensis (Coleoptera: Curculionidae). Plant Dis. 76:307-310.

30. Oomen, H. A. P. C., and Grubben, G. J. H. 1978. Tropical Leaf Vegetables in Human Nutrition. Communication 69, Dep. Agric. Res., Royal Tropical Institute, Amsterdam, Netherlands. Orphan Publishing Co., Willemstad, $\mathrm{Cu}$ racao.

31. Pamphile, J. A., and Azevedo, J. L. 2002. Molecular characterization of endophytic strains of Fusarium verticillioides (=Fusarium moniliforme) from maize (Zea mays L.). World J. Microbiol. Biotechnol. 18:391-396.

32. Pusey, P. L. 1989. Influence of water stress on susceptibility of nonwounded peach bark to Botryosphaeria dothidea. Plant Dis. 73:10001003.

33. Rawate, P. D. 1983. Amaranth (pigweed): A crop to help solve the world protein shortage. Pages 287-298 in: Environmentally Sound Agriculture: Selected Papers from the 4th International Conference of the International Federation of Organic Agriculture Movements. A. W. Lockeretz, ed. Praeger, NY.

34. Schoeneweiss, D. F. 1981. The role of environmental stress in diseases of woody plants. Plant Dis. 65:308-314.

35. Schoeneweiss, D. F. 1983. Drought predisposition to Cytospora canker in blue spruce. Plant Dis. 67:383-385.

36. Scholander, P. F., Hammel, H. T., Edda, D. Bradstreet, E. D., and Hemmingsen, E. A. 1965. Sap pressure in vascular plants. Science 148:339-346.

37. Smit, E., and McLaren, N. W. 1997. Effect of water stress on the colonization of maize roots by root-infecting fungi. Afr. Plant Prot. 3:4751 .

38. Swart, W. J., Conradie, E., Wingfield, M. J. and Venter, W. B. 1992. Effects of water stress on the development of cambial lesions caused by Cryphonectria cubensis on Eucalyptus grandis. Plant Dis. 76:744-746.

39. Tippett, J. T., Crombie, D. S., and Hill, T. C. 1987. Effect of phloem water relations on the growth of Phytophthora cinnamomi in Eucalyptus marginata. Phytopathology 77:246250. 